Infection

Edited by Andrew Lever MD FRCP, Professor of Infectious Diseases Addenbrooke's Hospital, Cambridge

\section{Recently introduced}

\section{antibiotics: a guide}

\section{for the general}

\section{physician}

Martin Wiselka MD PhD FRCP, Consultant Physician and Honorary Senior Lecturer, Department of Infection and Tropical Medicine, University Hospitals of Leicester NHS Trust, Leicester Royal Infirmary

\section{Clin Med 2004:4:494-8}

Recent years have seen the emergence of increasing bacterial resistance, including methicillin-resistant Staphylococcus aureus (MRSA), vancomycin (glycopeptide) resistant enterococcus (GRE) and highly resistant gram-negative organisms. These resistant bacteria have proved difficult to treat and control. The recent appearance of $S$. aureus with reduced sensitivity to glycopeptide antibiotics has raised the spectre of a common and serious bacterial infection that may be impossible to treat with current antibiotics.

Increasing antibiotic resistance has become an issue of national concern (Fig 1). ${ }^{1,2}$ The inexorable spread of multiresistant organisms can be slowed by the judicious use of antibiotics and more vigorous infection control measures, but new antibiotics are also required to treat these infections. In addition, there is a need for well-tolerated, easily administered, broad-spectrum antibiotics to cover pathogens encountered in respiratory tract infections and other common conditions.

This article discusses the role of several recently introduced antibiotics.

\section{Linezolid}

Linezolid, a member of a new class of antibiotics, the oxazolidinones, which are unrelated to existing classes of anti-

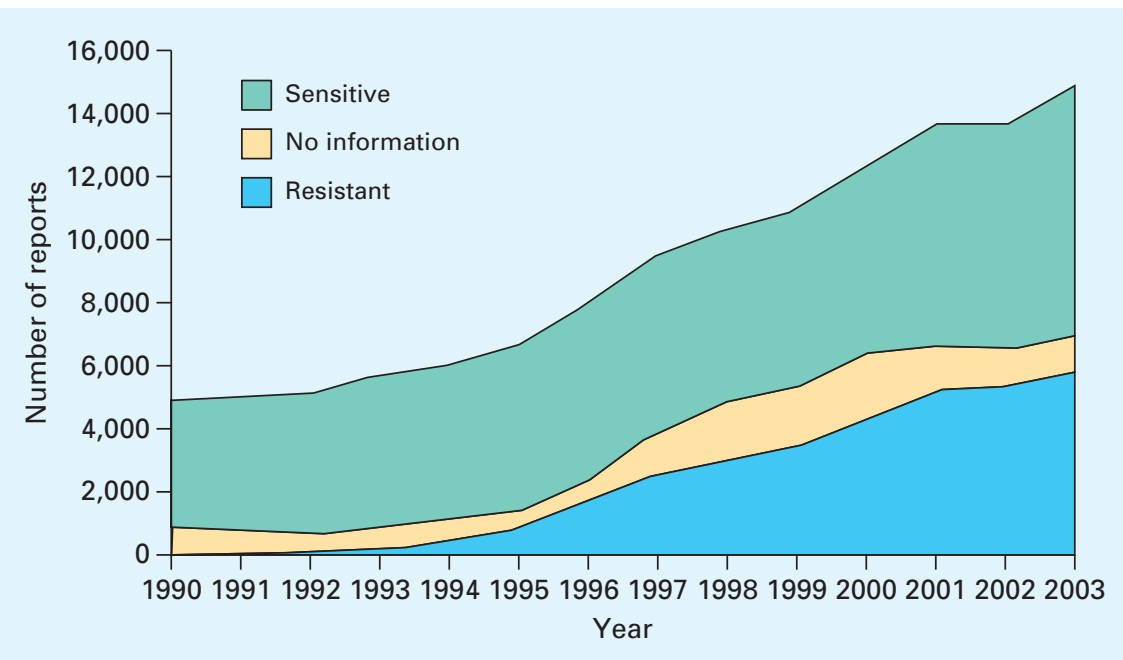

Fig 1. Staphylococcus bacteraemia and methicillin susceptibility (voluntary reporting scheme), England and Wales, 1990-2003. biotics (Table 1), is effective in vitro against gram-positive bacteria and a few gram-negative anaerobic bacteria. Linezolid has activity against staphylococci, pneumococci and enterococci, including those resistant to penicillin and vancomycin, its oral bioavailability approaches $100 \%$, there is excellent tissue penetration, and metabolised products are cleared by renal excretion. ${ }^{3}$

\section{Clinical studies}

Large clinical studies have shown that the efficacy of linezolid is at least equivalent to comparable established antibiotics in the treatment of skin and soft tissue infections, including invasive MRSA infections, community-acquired pneumonia (CAP), nosocomial pneumonia, bacteraemia in hospitalised patients and GRE infections. ${ }^{4}$

\section{Adverse effects}

Linezolid is usually well tolerated and drug levels do not need to be measured. Adverse effects include diarrhoea, nausea, headache, haematological effects including thrombocytopenia, associated with long-term use (generally over four weeks) and rarely pseudomembranous colitis. The Committee on Safety of Medicines advises that full blood counts be monitored weekly. It also recommends close monitoring for patients receiving treatment for longer than two weeks and those with severe renal impairment, at particular risk of myelotoxicity (eg pre-existing myelosuppression) or taking other myelosuppressive drugs.

Neuropathy, both peripheral and optic, has also been reported, usually following long-term use. Linezolid is a weak reversible inhibitor of monoamine oxidase (MAO). This seems to have little clinical relevance but the drug should not be administered concomitantly with or within two weeks of stopping an MAO inhibitor.

\section{The place of linezolid}

The introduction of linezolid has undoubtedly been an important mile- 
stone in the development of new antibiotics. ${ }^{5}$ The drug is already in widespread use, with a particular role in the treatment of MRSA and GRE infections. The inhibition of protein synthesis may be of particular relevance in the treatment of toxin-forming organisms such as Streptococcus pyogenes and toxigenic strains of staphylococci. Its excellent tissue penetration is important for the treatment of deep-seated infections including osteomyelitis, while the good oral bioavailability allows early switching from intravenous to oral therapy. Clinical studies have demonstrated a decrease in the length of hospital stay in patients with skin and soft tissue infections treated with linezolid, which may offset the increased cost in comparison with other antibiotics. Resistance occurs rarely, but has been reported with prolonged use against Enterobacterium faecium infection.

As linezolid has a crucial role in the treatment of multiresistant grampositive infections, its use should be carefully controlled. The data sheet advises that linezolid should be initiated only in a hospital environment after consultation with a relevant specialist.

\section{Moxifloxacin}

Moxifloxacin is a newly introduced oral fluoroquinolone antibiotic with a broad spectrum of activity against bacterial and atypical pathogens (Table 1). Its particular advantage over earlier quinolones includes extended activity against gram-positive bacteria, ${ }^{6}$ but it has little activity against pseudomonas. In common with other quinolones, moxifloxacin has excellent oral bioavailability and tissue penetration. Drug concentrations in epithelial fluid and bronchial biopsies exceed those in plasma. The

Table 1.

\begin{tabular}{|c|c|c|c|c|}
\hline & Linezolid & Moxifloxacin & Telithromycin & Ertapenem \\
\hline $\begin{array}{l}\text { Antibiotic } \\
\text { class }\end{array}$ & Oxazolidinone & $\begin{array}{l}\text { Fluoroquinolone with an } \\
\text { 8-methoxyquinolone structure }\end{array}$ & $\begin{array}{l}\text { Ketolide; a semisynthetic } \\
\text { member of the macrolide- } \\
\text { lincosamide-streptogramin B } \\
\text { family of antibiotics }\end{array}$ & Carbapenem \\
\hline $\begin{array}{l}\text { Mechanism } \\
\text { of action }\end{array}$ & $\begin{array}{l}\text { Inhibits formation of the } \\
70 S \text { ribosomal initiation } \\
\text { complex, preventing } \\
\text { bacterial protein synthesis; } \\
\text { primarily bacteriostatic } \\
\text { action }\end{array}$ & $\begin{array}{l}\text { Inhibits topoisomerase II and } \\
\text { IV with bactericidal activity }\end{array}$ & $\begin{array}{l}\text { Inhibits bacterial protein } \\
\text { synthesis by direct binding } \\
\text { to the } 50 \text { S subunit of bacterial } \\
\text { ribosomes, preventing } \\
\text { translation and ribosome } \\
\text { assembly }\end{array}$ & $\begin{array}{l}\text { Attaches to penicillin binding } \\
\text { proteins, inhibiting bacterial } \\
\text { cell wall synthesis; bactericidal } \\
\text { activity }\end{array}$ \\
\hline $\begin{array}{l}\text { Spectrum } \\
\text { of activity }\end{array}$ & $\begin{array}{l}\text { Gram-positive bacteria and } \\
\text { a few gram-negative } \\
\text { anaerobic bacteria; active } \\
\text { against staphylococci, } \\
\text { pneumococci and } \\
\text { enterococci, including those } \\
\text { resistant to penicillin and } \\
\text { vancomycin }\end{array}$ & $\begin{array}{l}\text { Gram-positives, including } \\
\text { staphylococci, enterococci, } \\
\text { Streptococcus pneumoniae, } \\
\text { including penicillin resistant } \\
\text { strains; atypicals, including } \\
\text { legionella and Mycoplasma } \\
\text { pneumoniae; gram-negatives, } \\
\text { including Haemophilus } \\
\text { influenzae, Moraxella } \\
\text { catarrhalis, coliforms, Neisseria } \\
\text { gonorrhoeae; low activity } \\
\text { against pseudomonas and } \\
\text { some enterobacteriacae; active } \\
\text { against Mycobacterium } \\
\text { tuberculosis, including } \\
\text { multiresistant strains; inhibits } \\
\text { 9o\% of anaerobic bacteria } \\
\text { including clostridia, bacteroides, } \\
\text { fusobacterium, porphyromonas }\end{array}$ & $\begin{array}{l}\text { Gram-positives, including } \\
\text { Streptococcus pneumoniae } \\
\text { (including erythromycin } \\
\text { resistant strains), } \\
\text { Streptococcus pyogenes, } \\
\text { MRSA; some gram-negative } \\
\text { bacteria, including } \\
\text { Haemophilus influenzae, } \\
\text { Moraxella catarrhalis; atypicals, } \\
\text { including Mycoplasma } \\
\text { pneumoniae, Chlamydia } \\
\text { pneumoniae and legionella; } \\
\text { not active against } \\
\text { erythromycin-resistant strains } \\
\text { of MRSA }\end{array}$ & $\begin{array}{l}\text { Most enteric bacteria, } \\
\text { including those producing } \\
\text { beta-lactamase; gram-negative } \\
\text { respiratory pathogens, } \\
\text { including Moraxella catarrhalis } \\
\text { and Haemophilus influenzae; } \\
\text { gram-positive bacteria, } \\
\text { including Streptococcus } \\
\text { pneumoniae (including those } \\
\text { resistant to penicillin) and } \\
\text { MRSA; also effective against } \\
\text { many anaerobes, including } \\
\text { bacteroides, prevotella and } \\
\text { porphyromonas; limited } \\
\text { activity against Pseudomonas } \\
\text { aeruginosa acinetobacter, } \\
\text { enterococcus, lactobacillus, } \\
\text { MRSA }\end{array}$ \\
\hline $\begin{array}{l}\text { Licensed } \\
\text { indications }\end{array}$ & $\begin{array}{l}\text { Nosocomial pneumonia, } \\
\text { CAP; complicated skin and } \\
\text { soft tissue infections }\end{array}$ & $\begin{array}{l}\text { CAP; exacerbations of chronic } \\
\text { bronchitis; sinusitis }\end{array}$ & $\begin{array}{l}\text { CAP (mild or moderate), acute } \\
\text { exacerbations of chronic } \\
\text { bronchitis; acute sinusitis; } \\
\text { tonsillitis/pharyngitis caused } \\
\text { by group A streptococci as } \\
\text { an alternative when beta- } \\
\text { lactam antibiotics are not } \\
\text { appropriate }\end{array}$ & $\begin{array}{l}\text { Complicated intra-abdominal } \\
\text { infections; acute } \\
\text { gynaecological infections; CAP }\end{array}$ \\
\hline Dosing & $\begin{array}{l}600 \text { mg twice daily, oral } \\
\text { tablets or suspension and } \\
\text { iv infusion }\end{array}$ & $400 \mathrm{mg}$ once daily orally & 800 mg once daily orally & $\begin{array}{l}1 \mathrm{~g} \text { once daily iv for up to } \\
14 \text { days; reduced dosage in } \\
\text { renal impairment }\end{array}$ \\
\hline
\end{tabular}

$\mathrm{CAP}=$ community-acquired pneumonia; iv = intravenous; $\mathrm{MRSA}=$ methicillin-resistant Staphylococcus pneumoniae 
drug penetrates cerebrospinal fluid and is highly concentrated within macrophages. Clearance is partially renal but predominantly through bile excretion; moxifloxacin may be used safely, with no dose adjustments, in patients with mild to moderate renal and hepatic failure. The half-life is 9-12 hours and single daily dosing is recommended.

\section{Clinical studies}

Moxifloxacin is comparable to amoxycillin and clarithromycin in the treatment of mild to moderate community-acquired suspected pneumococcal pneumonia in adults. ${ }^{6}$ In exacerbations of chronic bronchitis, a five-day course of moxifloxacin gave results equivalent to a seven-day course of levofloxacin. Further studies comparing moxifloxacin and amoxycillin, clarithromycin or cefuroxime have shown similar clinical success rates at the end of therapy. A five-day course of moxifloxacin gave a superior bacteriological response $(77 \%)$ than a seven-day course of clarithromycin $(62 \%){ }^{6}$ More recently, moxifloxacin treatment of exacerbations of chronic bronchitis resulted in a higher microbiological cure rate and fewer exacerbations over the study follow-up period (up to nine months) than in patients receiving standard antibiotics (amoxycillin, clarithromycin or cefuroxime). ${ }^{7}$

In chronic sinusitis, moxifloxacin is equivalent to co-amoxiclav or oral cefuroxime axetil, but higher bacteriological eradication rates were achieved $(94.5 \%)$ than with cefuroxime $(83.5 \%),{ }^{8}$ with particular benefit in patients with penicillin resistant Streptococcus pneumoniae.

\section{Adverse effects}

Moxifloxacin is well tolerated. Side effects include nausea and diarrhoea in $6-7 \%$ of patients and dizziness is occasionally reported. QT prolongation has been observed and moxifloxacin is contraindicated in patients with a history of significant arrhythmias or clinical heart failure with reduced left ventricular ejection fraction. There are no relevant interactions with theophylline or warfarin.

\section{The place of moxifloxacin}

There is no doubt that moxifloxacin offers an effective alternative to current treatments for CAP; its efficacy against all commonly encountered respiratory pathogens allows a once daily single dose for nearly all patient groups except those

\section{Key Points}

Antibiotic resistance is an increasing problem

Oxazolidinones are the only new class of antibiotics to be developed in the last 30 years

Linezolid is active against gram-positive organisms including methicillin-resistant Staphylococcus aureus and (vancomycin) glycopeptide-resistant enterococcus

Linezolid has excellent oral bioavailability which has been associated with reduced hospital inpatient stay

Moxifloxacin can be used as a single agent in community-acquired pneumonia (CAP). Treatment of infective episodes of chronic obstructive pulmonary disease may reduce the number of subsequent exacerbations in comparison with other antibiotics

Telithromycin is a ketolide antibiotic related to the macrolides and can be used as single agent therapy for CAP

Ertapenem is a once daily carbapenem antibiotic effective in intra-abdominal and gynaecological infections

KEY WORDS: antibiotic resistance, ertapenem, GRE, linezolid, moxifloxacin, MRSA, telithromycin likely to be colonised with pseudomonas. The efficacy of moxifloxacin against penicillin-resistant pneumococcus is important. A recent appraisal concluded that moxifloxacin offered no compelling advantages over established treatments, ${ }^{9}$ but the apparent prolonged benefit in chronic bronchitis and its efficacy in tuberculosis require further investigation.

\section{Telithromycin}

Telithromycin, a newly licensed oral antibiotic, is the first licensed compound belonging to the ketolide family. ${ }^{10}$ It has a broad spectrum of activity, particularly against respiratory pathogens, and low cross-resistance with other macrolides (Table 1). ${ }^{10}$ It is thought to have a low potential for the development of resistance. There is good oral bioavailability and concentration in tissues including tonsils, bronchopulmonary tissues and alveolar macrophages. ${ }^{11}$ The recommended dose is $800 \mathrm{mg}$ once daily. Elimination is by several pathways. including faecal and urine excretion and liver metabolism.

\section{Clinical studies}

Clinical trials have been performed in patients with respiratory tract infections. In $\mathrm{CAP},{ }^{10}$ a $7-10$ day course was as efficient as treatment with quinolones, amoxycillin or clarithromycin. ${ }^{12}$ There was good efficacy against pneumococcal bacteraemia, in elderly patients and those with atypical respiratory pathogens. A five-day regimen of telithromycin was equivalent to 10-day courses of:

- cefuroxime or co-amoxiclav in acute exacerbations of chronic bronchitis

- co-amoxiclav in acute maxillary sinusitis

- penicillin or clarithromycin in group A streptococcal tonsillitis/ pharyngitis. ${ }^{10}$

\section{Adverse effects}

Telithromycin is generally well tolerated, although diarrhoea, nausea and occasional dizziness and vomiting have been reported. ${ }^{10}$ The rate of diarrhoea $(13.3 \%)$ is higher than with some com- 
parative agents although less than with co-amoxiclav (ca 18\%). Telithromycin inhibits CYP3A4, causing an interaction with ketoconazole and intraconazole that increases drug levels, but there is no significant effect on warfarin levels.

\section{The place of telithromycin}

With its broad spectrum of activity against respiratory pathogens, telithromycin can be used as monotherapy and will be of particular benefit where there is a high rate of pneumococcal resistance to penicillin and macrolides. The once daily dosing schedule and shorter period of duration of treatment (5 days) compared with other agents also offer potential advantages. Although telithromycin is a useful addition to the formulary, it has yet to be established as a frequently used antibiotic in the UK.

\section{Ertapenem}

Ertapenem, a broad-spectrum carbapenem antibiotic with activity against most gram-negative, gram-positive aerobic and anaerobic bacteria, ${ }^{13}$ is licensed for once daily parenteral administration (Table 1). It has good tissue penetration, a half-life of four hours and is predominantly eliminated by the kidneys. Unlike imipenem, ertapenem is stable to renal dihydropeptidase-1 (DHP-1) and therefore does not require the addition of a DHP-1 inhibitor (eg cilastatin). No dosage reductions are required in mild to moderate renal insufficiency (creatinine clearance $>30 \mathrm{ml} / \mathrm{min}$ ) and hepatic impairment.

\section{Clinical studies}

The efficacy of ertapenem was equivalent to:

- piperacillin/tazobactam ${ }^{13,14}$ or ceftriaxone plus metronidazole in complicated intra-abdominal infections

- piperacillin plus tazobactam in acute pelvic infections following obstetric and gynaecological procedures

- parenteral ceftriaxone in complicated urinary tract infections
- piperacillin/tazobactam in complicated skin and soft tissue infections, and

- ceftriaxone in CAP, ${ }^{15}$ with good success against both penicillin-susceptible and penicillin-resistant $S$. pneumoniae, although the data on the use of ertapenem in severe CAP are limited.

\section{Adverse effects}

Ertapenem is usually well tolerated. ${ }^{13}$ The most common adverse effects include diarrhoea (5\%), phlebitis at the site of infusion and nausea. Seizures were slightly more common in patients receiving ertapenem than piperacillin/ tazobactam $(0.5 \%$ vs $0.3 \%)$.

Fig 2. Complicated abdominal sepsis.

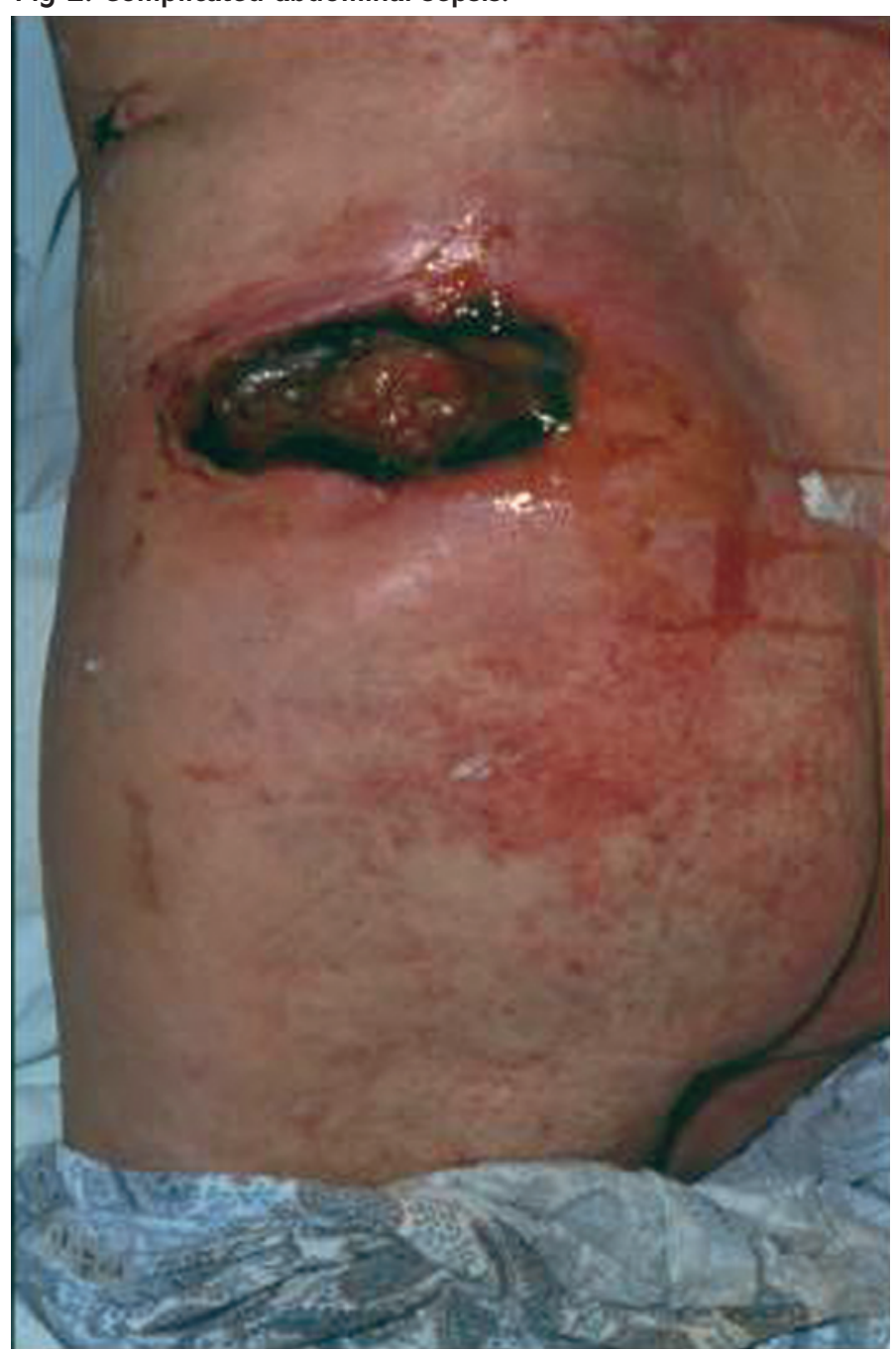

\section{The place of ertapenem}

The advantages of ertapenem over previously introduced carbapenems (imipenem and meropenem) include stability to hydrolysis by human renal DHP-1 and once daily administration. Ertapenem is well tolerated, has a broad spectrum of activity and is of particular value in complicated polymicrobial infections such as intra-abdominal sepsis (Fig 2).

\section{Conclusions}

The antibiotics discussed here have all been introduced in recent years. The pharmaceutical industry continues actively to pursue new compounds offering activity against resistant organisms or providing increasingly 
broad-spectrum cover. Although antibiotics continue to be developed, the oxazolidinones are the only truly new class of antibiotics to emerge over the past 30 years.

Drugs in the pipeline for the near future include a number of new agents against gram-positive infections including MRSA and GRE infections. This is clearly an area of intense interest to the pharmaceutical industry and several new agents are poised for clinical introduction. Second-generation oxazolidinones with a broader spectrum of action are being developed and further fluoroquinolones are undergoing clinical trials.

There is no doubt that these newly introduced antibiotics will offer significant advantages over established drugs. However, their use should be carefully controlled, ideally in the context of robust hospital antimicrobial policies and under the supervision of infection specialists.

\section{Conflicts of interest}

Dr Wiselka has been a principal investigator for clinical trials of linezolid and has received educational and travel grants from Pfizer and Bayer Ltd.

\section{References}

1 Department of Health 2002. Getting ahead of the curve: a strategy for combating infectious diseases. Available at: www.publications.doh.gov.uk/cmo/idstrategy/

2 Department of Health 2003. Winning ways. Working together to reduce healthcare associated infection in England. Available at: www.dh.gov.uk/assetRoot/04/06/46/89/040 64689.pdf

3 Diekema DJ, Jones RN. Oxazolidinone antibiotics. Review. Lancet 2001;358: 1975-82.

4 Perry CM, Jarvis B. Linezolid: review of its use in the management of serious gram-positive infections. Drugs 2001; 61:525-51.

5 Linezolid for gram-positive infections. Review. Drug Ther Bull 2001;39:54-6.

6 Balfour JA, Lamb HM. Moxifloxacin: a review of its clinical potential in the management of community-acquired respiratory tract infections. Review. Drugs 2000;59:115-39.

7 Wilson R, Allegra L, Huchon G, Izquierdo $\mathrm{JL}$ et al. Short-term and long-term out- comes of moxifloxacin compared to standard antibiotic treatment in acute exacerbations of chronic bronchitis. Chest 2004;125:953-64.

8 Siegert R, Gehanno P, Nikolaidis P, Bagger-Sjoback D et al. A comparison of the safety and efficacy of moxifloxacin (BAY 12-8039) and cefuroxime axetil in the treatment of acute bacterial sinusitis in adults. The Sinusitis Study Group. Respir Med 2000;94:337-44.

9 Moxifloxacin - new fluoroquinolone antibacterial. Review. Drug Ther Bull 2004;42:61-2.

10 Balfour JA, Figgitt DP. Telithromycin. Drugs 2001;61:815-29.

11 Muller-Serieys C, Andrews J, Vacheron F, Cantalloube C. Tissue kinetics of telithromycin, the first ketolide antibacterial. Review. J Antimicrob Chemother 2004;53:149-57.

12 Mathers Dunbar L, Hassman J, Tellier G. Efficacy and tolerability of once-daily oral telithromycin compared with clarithromycin for the treatment of community-acquired pneumonia in adults. Clin Ther 2004;26:48-62.

13 Curran MP, Simpson D, Perry C. Ertapenem: a review of its use in the management of bacterial infections. Review. Drugs 2003;63:1855-78.

14 Solomkin JS, Yellin AE, Rotstein OD, Christou NV et al. Ertapenem versus piperacillin/tazobactam in the treatment of complicated intraabdominal infections: results of a double-blind randomized comparative phase III trial. Ann Surg 2003;237:235-45.

15 Ortiz-Ruiz G, Caballero-Lopez J, Friedland IR, Woods GL et al. A study evaluating the efficacy, safety, and tolerability of ertapenem versus ceftriaxone for the treatment of community-acquired pneumonia in adults. Clin Infect Dis 2002;34:1076-83. 